\title{
YOUR LANGUAGE MY CULTURE (YLMC): DEVELOPING A LOCAL- CULTURE ELT MATRIX FOR SCHOOLS IN TERENGGANU, MALAYSIA
}

\section{Zawiah Yahya $^{1 *}$, Noraini Ibrahim ${ }^{1}$, Rashila Ramli ${ }^{1}$, Noraini Md Yusof ${ }^{1,2}$ and Zarina Othman ${ }^{1,3}$}

${ }^{1}$ Institute of Malaysian \& International Studies (IKMAS),

${ }^{2}$ Faculty of Social Sciences and Humanities,

${ }^{3}$ Pusat Citra, Universiti Kebangsaan Malaysia, MALAYSIA

"Corresponding author: zawiahyahya@ukm.edu.my

Published online: 25 September 2017

To cite this article: Zawiah Yahya, Noraini Ibrahim, Rashila Ramli, Noraini Md Yusof and Zarina Othman. 2017. Your Language My Culture (YLMC): Developing a local-culture ELT matrix for schools in Terengganu, Malaysia. Kajian Malaysia 35(2): 39-66. https://doi.org/10.21315/ $\mathrm{km} 2017.35 .2 .3$

To link to this article: https://doi.org/10.21315/km2017.35.2.3

\section{ABSTRACT}

This paper outlines details of a local-culture matrix that maps the cultural content of a supplementary, local-culture-based three-year reading programme in English for secondary schools in Terengganu, Malaysia. The reading programme, called "Your Language My Culture" (YLMC), is designed by a group of researchers from Universiti Kebangsaan Malaysia (UKM) with the objective of upgrading both English proficiency and local culture awareness at the same time. Two broadly opposing views on the use of local culture in English Language Teaching (ELT) are presented: one that favours the use of "authentic" cultural norms of native speakers of English in a process of "cultural assimilation"; the other that favours localising materials for ELT textbooks adapted to the local environment of English as a Second Language (ESL) learners. The YLMC programme adopts the latter view on the conviction that the learners' familiarity with local content and context will better facilitate learning and interaction with English. In the design of the culture matrix for ELT, the YLMC team has also taken cognizance of the global trends in pedagogy and the specific context of Terengganu where the programme is implemented.

Keywords: YLMC, matrix, local culture, English, reading 


\section{INTRODUCTION}

The local-culture matrix about to be unraveled here is specific to English Language Teaching (ELT) and to an English as a Second Language (ESL) programme to be used in a selected demographic and geo-political context. Specifically, the matrix is a mapping of the cultural coverage for a supplementary reading called Your Language My Culture (henceforth, YLMC), specially designed for three years of secondary school in Terengganu, Malaysia. As will unfold later, the local content used is mostly Terengganu-specific, Terengganu being a State of choice from Malaysia for a case study. Terengganu's demography facilitates research because it is one of the most homogenous states with more than $95 \%$ ethnically Malay population (Department of Statistics Malaysia Official Portal, n.d.) and therefore culturally monolithic enough to minimise variables and margins of error in the cultural mapping for textbook writing and programme evaluation procedures.

To understand YLMC and the spirit behind the project, there is a need to walk through the ESL context of Malaysia, study the various aspects of the reading programme envisaged for Terengganu and explore the concept of a cultural input in ELT pedagogy as the rationale for its existence, all of which have been taken on board in the making of the matrix.

\section{ESL IN MALAYSIA}

The story of English language in Malaysia shares almost the same narrative with other ESL countries in Kachru's outer circle (Kachru, 1992) and with other former colonies of Britain. During the history of British rule in these places, English was always made the official language for administration, education, commerce and law while local languages were marginalised (Ashcroft, Griffiths and Tiffin, 1989), the consequences of which have continued to shape post-independence language policies to this day.

Since Independence in 1957, Malaysian language policies have had to deal with national imperatives to replace English with Malay. The Education Act of 1961, based on the Razak Report of 1956 and the The Rahman Talib Report of 1960, reaffirmed the official position of Malay as national language and medium of instruction in schools to replace English consequently then relegated to the position of second language.

Then, from the 80s onwards, globalisation came and stayed. Now English once again reigns supreme as the lingua franca of a globalised communication system and the de facto language of business and international communication and a passport to lucrative employment both in the public and the private sectors and to upward mobility both professionally and socially. 
The desire to master this global language has become increasingly overpowering because of its international and economic value. There is even pressure from urban Malaysian parents to bring back the English-medium school system because they have seen how even "disadvantaged" Asian countries in Kachru's expanding circle (China, Japan, Korea, Thailand) are falling over one another in the quest for English proficiency (Zawiah, 2015).

As realities on the ground catch up with national ideals, language policies have gone through a period of reversals and compromises. For example, a controversial policy change was made in 2002 when the Ministry of Education decided to make English the medium of instruction for mathematics and science at all levels of the education system, to be implemented in stages. The policy promptly divided the nation into pro-Malay and pro-English factions.

Another reversal was made in 2002 that made a paradigm shift for bilingualism, as evident in the Ministry's promotional slogan: To uphold Malay; to strengthen English. It was clearly aimed at addressing the pro-English fear of lost opportunities in globalisation and the anti-English fear of losing national language and national identity. It was also meant to address the vexing issue of a steady drop in English language proficiency since the time when English-medium schools ceased to exist so that the country could be an effective global player of the economic scramble that comes with globalisation. In the 2013 English Lab under the Government Transformation Programme Management \& Delivery Unit (PEMANDU), it was found that 1,191 secondary schools had SPM English failure rates exceeding $23 \%$ with the problems particularly acute in the states of Sabah, Kelantan, Terengganu and Kedah.

Like the rest of Malaysia, Terengganu is also caught up in the linguistic ambivalence and national panic over falling standards of English. Statistics by the Terengganu Education Department show alarming failure rates in the last five years (The Sun Daily, 2016). The latest figures obtained from Jabatan Pendidikan Negeri Terengganu (JPNT) show a consistent failure rate for English in Terengganu since 2011: $29.1 \%$ in 2011, $28.7 \%$ in 2012, $24.5 \%$ in $2013,28.4 \%$ in $2014,28.6 \%$ in 2015 and $25.3 \%$ in 2016 . YLMC was partly designed in 2014 and launched in 2016 to help address this problem. Two of its project members who were Terengganu-born have already established strong connections with the State through their involvement in English Language activities there.

In short, English is not a simple proficiency issue in Malaysia. Between the perceived threats of English to the agenda for nation-building and the perceived economic value of English as an international language, between the desire for global English and the passion for preserving local cultural identities, the postIndependence nation has been caught in an endless ambivalence (Zawiah, 2003). The continuous reversals of language policies speak of short-term efforts to address this issue. 


\section{THE YLMC SUPPLEMENTARY READING PROGRAMME}

The YLMC was officially launched together with the Form 1 textbooks: the student copy (Zawiah et al., 2015a) and the teacher copy (Zawiah et al., 2015b) in January 2016 while the Form 2 textbooks were distributed to schools in February 2017. The Form 3 textbooks are scheduled for distribution in February 2018.

The YLMC plan is to first establish a context of collaboration and synergy between Yayasan Di Raja Sultan Mizan (YDSM, the funder), Universiti Kebangsaan Malaysia (UKM, the provider of English language experts) and JPNT (the Terengganu Department of Education with its network of teachers and education officers across the State). Equally important is the organisational synergy between three units of YLMC researchers from UKM working in tandem: the materials development team tasked with the writing and publication of textbooks; the research team tasked with conducting pilot and trace studies as well as programme evaluation (Ruzy et al., 2015); and the training team tasked with designing a special training programme for master-trainers to pass on the new methodology to English Language teachers across the State (Hazita et al., 2015).

The pedagogical argument behind the YLMC project is that the use of local cultural content as familiar reading schemata facilitates both English proficiency and cultural awareness. The culture matrix is a map devised to plot the cultural coverage for the content of the three-year programme which, when interfaced with the language matrix, will be its "syllabus". The main objective of the YLMC programme is to upgrade both English proficiency and cultural enrichment by providing local-culture content through reading, leading to better performance of oral and written communication in English. The other objectives are to develop an appreciation of local culture, society and its values as well as to nurture a local reading perspective when reading texts in the English.

It is hoped that there will be a good wash-back effect on the students besides improving their English proficiency. Firstly, in the process of learning a second language students will also gain awareness of the richness of their own heritage, thus strengthening their cultural identity. Secondly, they will also pick up the right vocabulary and appropriate language to explain, speak and write in English what they now know of their own culture and heritage. Thirdly, they will understand the relatedness of what they read to the realities of their everyday lives in their own society. Lastly, when they read for information and knowledge in English, they will learn to develop their own perspectives rooted in their value system.

Most importantly, we hope that this method of teaching and learning will help eliminate the linguistic ambivalence that has beset the country for so long by minimising the fear associated with cultural loss and the fear of lost economic opportunities associated with lack of proficiency in a global language. We hope to 
do this by creating a feel-good perception of English as an enabler, not a destroyer, of national goals.

YLMC does not replace but supplement the national syllabus. The national syllabus is an overarching framework within which supplementary programmes like YLMC need to operate. According to JPNT, students in Terengganu receive 200 minutes per week of English Language lessons and any supplementary programme must find its place within this limit. Currently, there are three supplementary English programmes for secondary schools sharing the time quota: YLMC, Trenglish and the Fullbright Teaching Assistance Programme. YLMC is, however, the only programme that requires a full period classroom session.

The national syllabus is structured on themes and levels of language proficiency where culture is not a content focus but a general setting for language instructions and activities. The Forms 1-3 textbooks used in Terengganu (Tan et al., 2002; Shanta, Kurup and Lorenz, 2003; Choo, Low and Anthony, 2004) show a spread of Malaysian and international/Western contexts that provide the general background for ESL language lessons. Overall, though, there is a commendable effort to gradually expose students beyond the familiar to the world outside Malaysia. Keeping in mind that the focus of the national syllabus is on language proficiency and not on cultural studies per se, it is to be expected that the "cultural" content of the current textbooks will not take on board specific local cultural elements for cultural enrichment. YLMC is, therefore, only filling in the culture gap by providing local culture reading as another effective pedagogical instrument to improve not only language proficiency but also cultural awareness. It also attempts to balance preoccupation with Western literary texts by interfacing them with local literary works.

Our preliminary analysis of textbooks used in Terengganu shows that, while the Malaysian contexts are used for the teaching of Language for Interpersonal Use and Language for Informational Use, Western texts are preferred for Language for Aesthetic Use. For instance, while all 16 chapters of the Form 1 Textbook, 13 (out of 15) chapters in the Form 2 Textbook and 10 (out of 15) chapters in the Form 3 Textbooks use Malaysian contexts, the texts for Language for Aesthetic Use include excerpts from Robinson Crusoe, Potato People, Phantom of the Opera, Dr Jekyl \& Mr Hyde and Prisoner of Zenda. In fact, in one study investigating the place of local literature in the English Language Subject for Secondary Schools in Malaysia, the researchers conclude that "more attention needs to be paid to the inclusion of local literature as it can be an important communicator of signifiers of ethnic identity and subsequently play an important role in facilitating interethnic engagement and understanding in Malaysian schools" (Pillai, Menon and Vengadasamy, 2016: 25). YLMC textbooks give priority to materials that foreground issues and concerns relevant to Terengganu as a conscious effort to engage students with their culture and heritage whilst learning English. Noritah 
and Washima (2008) too have argued on the need for inclusiveness in literary texts that focus on the Malaysian identity even for primary schools.

The focus of YLMC is on reading. It is true that reading programmes have been introduced in secondary schools since the establishment of Bahasa Malaysia as the official medium of instruction in 1970. These included the English Language Reading Programme (ELRP) implemented in 1983 (Edwin, 1993; Ganakumaran, 2003) and the Class Reader Programme (CRP) in 1993 (Ganakumaran, 2003; Raj and Hunt, 1990). However, unlike YLMC, these programmes were not accompanied by specific language activities to enhance proficiency. It is also true that in 1999, the Literature Component was incorporated in the English Language Syllabus but, according to Pillai, Menon and Vengadasamy (2016), out of 25 literary texts used in the first cycle (2001-2010), 8 were local titles and 17 were foreign texts. When the second cycle of corpus was introduced in 2011, out of the 25 texts introduced, only 5 were local. When a third corpus was introduced in 2015, local writers were again marginalised. Hence, this trend of text selection for reading in English for Malaysian learners is an on-going concern. Emphasising local culture and heritage in the selection of texts for reading, which is central to YLMC, is meant to address this concern.

\section{CONCEPT OF LOCAL-CULTURE INPUT FOR ELT}

There are two opposing views on the use of culture in ELT. One view (Byram, 1997; Byram and Fleming, 1998) is that English language and English culture are inseparable in ELT and that learning materials must integrate the linguistic and cultural norms of the native speakers of English in Kachru's Inner Circle. In other words, you cannot teach a target language without teaching the target culture in a process called "cultural assimilation" of the "authentic".

The other view (Kachru, 1986; Kachru and Nelson, 1996; Canagarajah, 1999) favours localising the materials and making ELT textbooks more culturally responsive to the needs of non-English learners by using their experiences in their own local contexts. A pedagogy of the appropriate, instead of the authentic, should be adapted to local cultural environment (Widdowson, 1994). Canagarajah (1999) has outlined elements of a critical pedagogy suitable for ELT in formerly colonised communities. ELT textbooks that focus on the target (English) culture have been found to create an alienating effect on ELS learners who would resist such cultural assimilation and end up with apathy for the target language (Gray, 2000).

YLMC adopts the second view as a guiding principle for the design of its reading programme. It recognises that the sense of learner "disengagement" mentioned is one of the causes of apathy towards English especially in the rural ethnically Malay heartland which largely makes up Terengganu. The Inner Circle 
culture (of USA, UK, Australia, New Zealand and Canada) cannot provide "appropriate" cultural content to arouse interest and attention, leave alone to sustain them, in a real classroom situation. Children of fishermen along the coast (in the JPNT category of "sekolah pantai"), children of oil palm growers (in the category of "sekolah FELDA") and children in the interior of Terengganu (in the category of "sekolah pendalaman") are all twice removed, linguistically and culturally, from the culture of the authentic of the target language.

The YLMC team believes these are sound pedagogical principles. To teach a language well we should start with the familiar. English is an unfamiliar variable and the western cultural baggage it carries is culturally distant from young Terengganu learners. To put it plainly, to work with familiar content and context will greatly facilitate language learning.

The pedagogy of the appropriate in the use of familiar local material remains an issue in the current millennium years (Kirkpatrick, 2007; McKay, 2003a; Wang and Hill, 2011). In 2007, Kirkpatrick researched on the development of culturally appropriate ELT materials for Indonesian tertiary students that were modified by local Indonesian teachers and writers. The project called the "Asianculture based project" produced an English textbook for Indonesian university students (Aminudin, Dadang and Safrina, 2003). Kirkpatrick poses that instead of giving students information about the cultures of native speakers:

...the curriculum should include information about the cultures and peoples of the ASEAN and Asian regions. It is also important that students be prepared to be able to use English to talk about their own cultures and issues which are important to them (2007: 23).

McKay (2003b) argues that when teaching English as an international language, educators should recognise the value of including topics that deal with the local culture, support the selection of a methodology appropriate to the local educational context, and recognise the strengths of bilingual English teachers. She says that in Chile, growing support on using local culture in ELT has generated great interest in countries where English is a required subject. Wang and Hill (2011) further emphasise the need to develop learners' competence in communicating local values and traditions to the people of other cultures, whether they are from English or non-English speaking countries.

YLMC pedagogy is simple: make English learning practical and comfortable for our non-English speaking learners. Take out the fear, the anxiety and the ambivalence in the learning process. Start with the familiar (their own local experiences and culture) because Western content is an unfamiliar, alien and intrusive variable. Familiarity with local culture facilitates learning of ESL by making associations between English and learner's experience. Local contextualisation enables learners to be more interactive with English. 
As for the rationale in the use of local culture for cultural enrichment, YLMC has taken note of the influence of instructional materials on attitudes of self, identity and society. It has decided it is a matter of survival to join the current trend for "English for Specific Cultures" in the times of globalisation. The trend is part of our culture preservation efforts in the face of cultural imperialism. Many linguists have spoken of the influence of globalisation on small and vulnerable cultures (Pennycook, 1998; Crystal, 1997) such as ours. Pennycook (1998) warns how global English is "constantly pushing other languages out of the way, curtailing their usage in both qualitative and quantitative terms" (1998: 14). Similarly Crystal has warned us that it is "inevitable that, in the post-colonial era, there should be a strong reaction against continuing to use the language of the former colonial power, and in favour of promoting the indigenous languages" (Crystal, 1997:114)

The $Y L M C$ stand is that while promoting English language proficiency, it is necessary to be pro-active in dealing with the irreversible impact of global English that is fast changing language policies and marginalising local language, culture and values of non-English speaking countries around the globe. One effective way of doing it is to domesticate the language and give it a local habitation.

\section{DEVELOPING A LOCAL-CULTURE MATRIX}

The function of a culture matrix for the YLMC programme is to map out the coverage of culture content on which language activities are constructed for ELT. It will circumscribe what type of cultural elements, issues and topics are deemed appropriate for learners to explore for their levels of maturity and proficiency.

Once the cultural components are selected, categorisation is needed to sort out the myriad details to avoid content overlapping. Cultural content is divided into four tracks on which the cultural load is delivered to learners in stages for three years from Form 1 through to Form 3. The four tracks will make sure that diverse areas in the varied cultural landscape of Terengganu are adequately covered. The tracks are labeled Heritage, About Language, Literature, and Society \& Values. For each track, there are three sets of issues and topics that need to be covered in three lessons for every textbook, making it 12 lessons in all for each year.

The Appendix (refer to pages 54-66) outlines the culture content of the Heritage track (Appendix: refer to pages 54, 57, 62-63) for Forms 1-3 in its entirety so that the mapping will also illustrate the links made between cultural issues (mostly of survival and preservation), lesson topics, cultural content, and expected outcome of language proficiency and cultural awareness. The Heritage track is necessary because it is important that students understand what they have inherited from their own local tradition that has undoubtedly given them their cultural identity. The plan is to navigate them through carefully selected details 
of Terengganu-specific crafts such as wood-carving, batik and songket making, traditional boat and house building, ancient performing arts as well as traditional rites and rituals.

The same process is repeated for the track About Language (Appendix: refer to pages 54-55, 58, 63-64) which deals with local language issues involving, among others, the Malaysian variety of English, differences between language use in formal, informal and social media contexts, the process of word borrowing, social and digital identity, and language for specific disciplines. Complex concepts of language issues are simplified by breaking them down into familiar everyday contexts to give lower secondary ESL students some basic idea and a little awareness of larger and more complex language problematics.

The Literature track (Appendix: refer to pages 55-56, 59-60, 64-65) brings literary reading materials from the students' backyard into the classroom. Local writings, in the form of myths and legends, poetry, songs and drama, are sometimes interfaced with Western and non-Malaysian works prescribed by the national syllabus so that students can cross into the boundaries of the unfamiliar to seek enlightenment while keeping their feet firmly on home ground. For instance, in one lesson, comparisons are made between the role of Merlin in the myth of King Arthur and the shaman in the myth of Princess Ulik Mayang. In another lesson, issues of re-reading local folklore on the topic of Pak Pandir involves an understanding of local and Western perspectives of this character (Appendix: refer to page 55-56). The history of Terengganu is approached from the topic of "Batu Bersurat" (Inscribed Stone) through visual representations and poetry (Appendix: refer to pages 59 ).

The track on Values \& Society (Appendix: refer to pages 56, 60-61, 65-66) deals mainly with local themes of patriotism, natural disasters and contributions of local personalities in sports, education, religion and charity work. However, some effort is made to link the present to the past: for instance, between the sea voyage of Abdullah Munsyi to Terengganu in the 19th century and the Terengganu maritime landscape of what it has become in the 21st century (Appendix: refer to pages 60); or between the ancient Muslim pioneers in Science and the development of future Malaysian scientists. This track is an open multi-disciplinary avenue for students to be informed beyond the limited boundaries of their existence.

The final step in constructing the YLMC Culture Matrix is to determine the intended student outcomes for each culture content selected for use in classroom teaching (see Appendix for Heritage; for About Language; for Literature; and for Values \& Society). For instance, the use of the Heritage content on traditional Terengganu food should go beyond an appreciation of local cuisine into an understanding of different ways of cooking in different cultures or a recognition of Eastern and Western ingredients (Appendix: refer to page 54). Similarly, the use of cultural content on a world class sportsman from Terengganu in an actual 
lesson should ultimately provide the students with the ability to identify what goes into the making of a local hero leading, perhaps, to an open-minded acceptance of different perspectives on the hero concept (Appendix: refer to page 56).

This culture mapping carefully crafted between what is possible for teaching and what is possible for learning will be the basis for constructing the entire YLMC Culture Matrix for Forms 1-3 which is officially named The YLMC Local-Culture Matrix for Terengganu 2016. (refer to Appendix for Form 1: pages 54-56; for Form 2: pages 57-61; for Form 3: pages 62-66). The YLMC Culture Matrix for Forms 1-3 contains the cultural content and corresponding outcomes of cultural enrichment expected from learners at each stage of their development. This Matrix, however, is only half the story. It needs to be interfaced with a reading matrix that outlines corresponding language proficiency outcomes.

\section{INTERFACING THE CULTURE MATRIX WITH A READING MATRIX}

Developing content for a reading programme is the first step to its operationalisation. Hence, once the culture matrix was ready, a reading matrix that would produce the desired language outcomes was sought. To this end, the YLMC team opted for Hess' Cognitive Rigor Matrix (CRM) (2004; 2009), as it best fits the objectives of the programme and the matrix comprised two of the most effective teaching and learning taxonomies. Hess' CRM was built by superimposing Bloom's (1956) revised taxonomy by Anderson et al. (2001) on educational objectives and Webb's (1997; 1999) Depth-of-Knowledge (DOK) levels.

In brevity, what this CRM does is to match the cognitive demands of Bloom's with the rigor of DOK necessary for the students to complete a task. This matrix has five columns with the first being Bloom's Taxonomy, comprising its six descriptors at increasing levels of cognitive demands (Remember, Understand, Apply, Analyse, Evaluate, Create). The next four columns are dedicated to Webb's four DOK levels (Recall and Reproduction, Skills and Concepts, Strategic Thinking and Extended Thinking) as shown in Table 1.

So how is this reading matrix operationalised? If we look at Bloom's lowest descriptor, which is Remember, and read across Webb's DOK, we will note that this cognitive skill (Remember) is matched by the lowest depth of knowledge (Recall and Reproduction). Hence, students need only to, for example, recall, locate or recognise certain facts or events from the reading. It is a mere identification of a fact and as a cognitive skill, Remember is not located within DOK 2 to DOK 4. In the same vein, Bloom's fifth and sixth levels (Evaluate and Create) require a high level of DOK and do not involve Recall and Reproduction, so there is a blank for DOK 1 and 2 where Evaluate and Create are concerned. Table 2 shows how the two matrices are interfaced. 

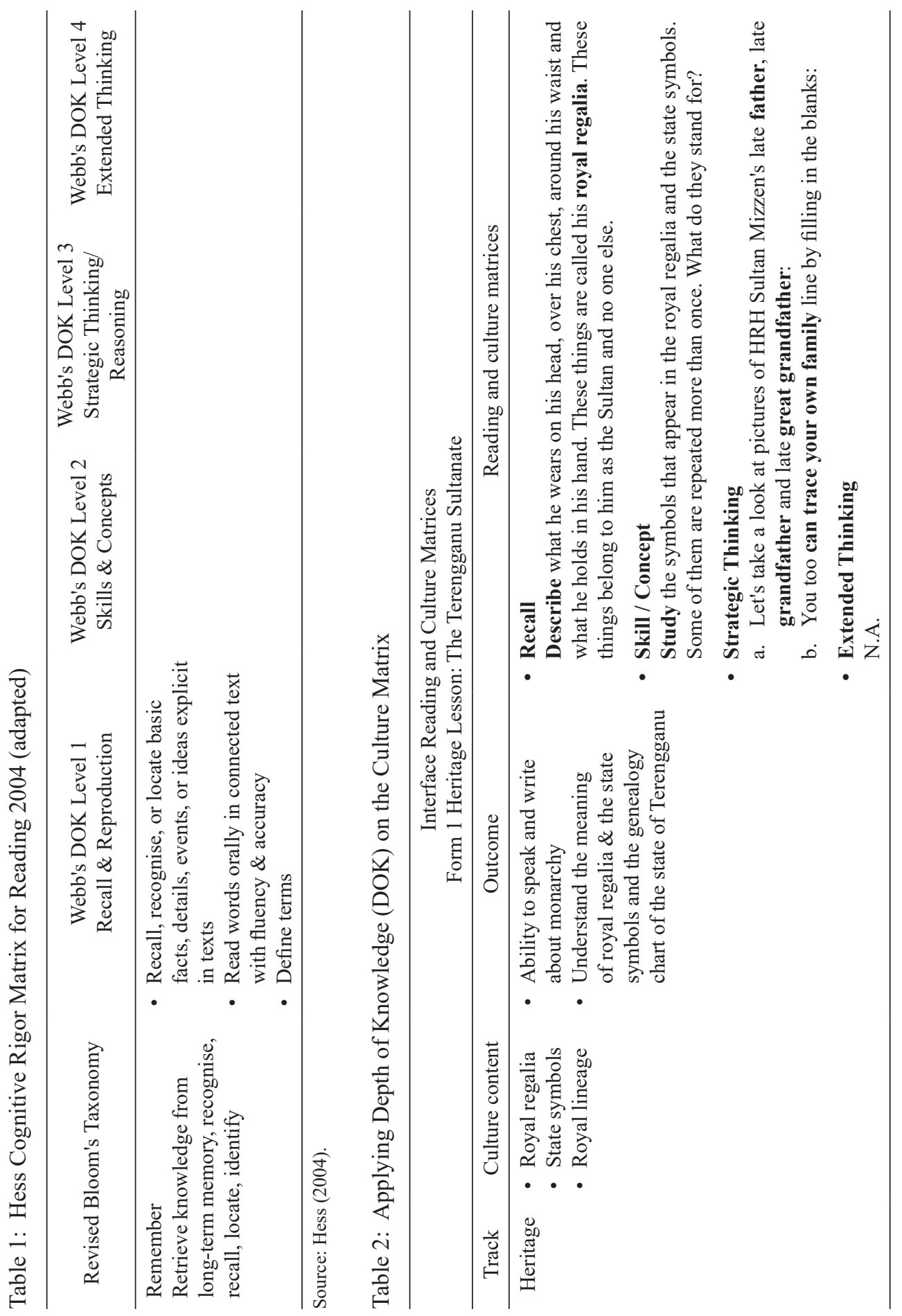
Using a sample from the Form 1 lesson on Heritage, which is on the Terengganu Sultanate, a reading lesson was designed. The first column is the track (Heritage), the second is the culture content covered in the lesson and the third are the learning outcomes. The fourth column is the interface of the Reading matrix (Bloom's Taxonomy and Webb's DOK) and the culture content of the lesson on Heritage. The students were asked to Describe (DOK 1), Study (DOK 2) and Trace your own family (DOK 3), an exercise that required them to go beyond the reading text and the classroom. In this lesson, only three out of the four DOK levels were applicable as the text and tasks did not lend themselves to DOK 4 (Extended Thinking). This same process of identifying the outcomes and DOK was repeated for all the four tracks and all the lessons covered in YLMC.

\section{CONCLUSION}

We are encouraged by the positive results of our pilot study and encouraging feedback from our training team. Teacher feedback on lesson coverage and student response has been an on-going process and points towards sustainable use. For example, the post-test results of the questionnaire show a significant increase in interest in learning English. Teachers discovered that students were excited to learn about their culture and were less inhibited when speaking English. The incorporation of local culture into this new syllabus seem to have enabled teacher creativity and the use of 21 st century classroom skills such as collaboration, cooperation and problem solving.

According to the same study, students viewed the YLMC programme as encouraging their involvement and interaction in the classroom. They were keen to ask more questions about their own culture, retrieve their content schemata, take part in sharing sessions and were more willing to share their experiences in class. They were excited to source information on Terengganu tradition and culture including personalities and folklore. Generally, they were interested to read up on Terengganu and write on it. Students found teachers to be more creative because they brought more interesting materials on the Terengganu local culture to class. Students were more willing to try out poetry reading, short sketches and performances.

These initial findings and student feedback strongly support the rationale for pedagogy of the appropriate within the Malaysian context. The Cognitive Rigor Matrix, as a framework, has also been found to be effective for the lesson designers. It provides the parameters for coverage and synergy between language and reading performances of local culture. This is the strength of the interface between Hess' Cognitive Rigor Matrix and Webb's DOK into the culture matrix. 
This YLMC Local-culture Matrix prototype has been designed for a homogeneous community, but it can be replicated and adapted in other states in Malaysia with a more heterogeneous population, or even in other countries facing the same language dilemma and fearing the loss of their own cultures in the face of globalisation. In such culturally diverse contexts, the cultural mapping will have to be different to reflect the diversity of the local population.

\section{ACKNOWLEDGEMENTS}

This study was funded by Yayasan DiRaja Sultan Mizan. Grant name: "Your Language My Culture": Supplementary English Language Reading Programme for Secondary Schools. Project Code: OO-2015-006.

\section{REFERENCES}

Anderson, L. W., D. R. Krathwohl, P. W. Airasian, K. A. Cruikshank, R. E. Mayer, P. R. Pintrich, J. Raths and M. C. Wittrock. 2001. A taxonomy for learning, teaching, and assessing: A revision of Bloom's taxonomy of educational objectives. New York: Pearson, Allyn \& Bacon.

Ashcroft, B., G. Griffiths and H. Tiffin. 1989. The empire writes back. London: Routledge. https://doi.org/10.4324/9780203426081.

Aminudin Aziz, Dadang Sudana and Safrina Noorman. 2003. Culture-based English for college students. Jakarata: Grasindo.

Bloom, B. S., ed. 1956. Taxonomy of educational objectives, handbook I: The cognitive domain. New York: David McKay Co Inc.

Byram, M. and M. Fleming 1998. Language learning in intercultural perspective. Cambridge: Cambridge University Press.

Byram, M. 1997. Teaching and assessing intercultural communicative competence. USA/ UK: Multilingual Matters Ltd.

Canagarajah, A. S. 1999. Interrogating the "Native speaker fallacy": Non-linguistic roots, non-padagogical results. In Non-native educators in English language teaching, ed. G. Braine, 77-93. Mahwah, NJ: Lawrence Erlbaum.

Choo, W. Y., K. P. Low and S. M. Anthony. 2004. English Form 3. Kuala Lumpur: Eliteguh Industries Sdn. Bhd.

Crystal, D. 1997. English as a global language. Cambridge, UK: Cambridge University Press.

Department of Statistics Malaysia. n.d. Official portal. https://www.statistics.gov.my (accessed 10 October 2016).

Edwin, M. 1993. Teaching literature in English in Malaysian secondary schools. In Teaching literature: A world perspective, eds. C. J. Brumfit and. M. Benton, 4449. London: Macmillan. 
Ganakumaran, S. 2003. Literature programmes in Malaysian schools: A historical overview. In Teaching of literature in ESL/EFL contexts, ed. G. Subramaniam, 27-48. Petaling Jaya: Sasbadi Sdn. Bhd.

Gray, J. 2000. The ELT coursebook as cultural artefact: How teachers censor and adapt. ELT Journal 54(3): 274-283. https://doi.org/10.1093/elt/54.3.274.

Hazita Azman, Rashila Ramli, Rosniah Mustafa, Noraini Md Yusof, Zarina Othman and Noraini Ibrahim. 2015. Teacher training compendium. YLMC Monograph. Unpublished.

Hess, K., B. S. Jones, D. Carlock and J. R. Walkup. 2009. Cognitive rigor: Blending the strengths of Bloom's Taxonomy and Webb's Depth-of-Knowledge to enhance classroom-level processes. [Technical report]. Retrieved from ERIC database. (ED517804). http://www.eric.ed.gov/PDFS/ED517804.pdf. (accessed 10 October 2016).

Hess, K. 2004. Applying Webb's Depth-of-Knowledge (DOK) levels in reading. http://www.nciea.org/publications/DOKreading_KH08.pdf (accessed 10 October 2016).

Kachru, B. B. and C. I. Nelson. 1996. World Englishes. In Sociolinguistics and language teaching, eds. S. L. McKay and N. H. Hornberger. Cambridge: Cambridge University Press.

Kachru, B. B. 1992. The other tongue: English across cultures. Urbana, IL: University of Illinois Press.

. 1986. The power and politics of English. NY: Pergamon Press.

Kirkpatrick, A. 2007. Teaching English across cultures. What do English language teachers need to know how to teach English. EA Journal 23(2): 20-36.

McKay, S. L. 2003a. Toward an appropriate EIL pedagogy: Reexamining common ELT assumptions. International Journal of Applied Linguistics 13(1): 1-22. https:// doi.org/10.1111/1473-4192.00035.

. 2003b. Teaching English as an international language: The Chilean context. ELT Journal 57(2): 139-148.

Noritah Omar and Washima Che Dan. 2008. Multiculturalism and Malaysian children's literature in English. The English Teacher XXXVI: 1-19.

Pennycook, A. 1998. English and the discourse of colonialism. NY: Routledge.

Pillai, S., P. S. Menon and R. Vengadasamy. 2016. The marginalisation of Malaysian texts in the English language curriculum and its impact on social cohesion in Malaysian classrooms. Kajian Malaysia 34(2): 25-58. http://dx.doi.org/10.21315/ $\mathrm{km} 2016.34 .2 .2$

Raj, D. and B. Hunt. 1990. The Malaysian class reader programme. Reading in a Foreign Language 6(2): 369-382.

Ruzy Suliza Hashim, Radha M. K. Nambiar, Ruhizan Mohammad Yasin and Wan Rosmanira Ismail. 2015. Research matters: Assessing effectiveness. YLMC Monograph. Unpublished.

Ruzy Suliza Hashim and G. Subramaniam. 2003. Reclaiming places and spaces: Issues in new literatures. Bangi: Universiti Kebangsaan Malaysia Press.

Shanta, R., U. Kurup and S. Lorenz. 2003. English Form 2. Petaling Jaya: Penerbit Mega Setia Emas Sdn. Bhd. 
Tan, B. K., B. Foo, S. K. Lim, C. Ong and A. L. H. Tan. 2002. English Form 1. Petaling Jaya: Sasbadi Sdn. Bhd.

The Straits Times. 11 December 2015.

The Sun Daily. 20 September 2016.

Wang, H. and C. Hill. 2011. A paradigm shift for English language teaching in Asia: From imposition to accommodation. The Journal of Asia TEFL 8(4): 205-232.

Webb, N. 1999. Alignment of science and mathematics standards and assessment in four states (NISE Research Monograph No.18). Madison: University of Wisconsin Madison, National Institute for Science Education. Washington, DC: Council of Chief State School Officers.

. 1997. Research monograph number 6: Criteria for alignment of expectations and assessments on mathematics and science education. Washington, D.C.: Council of Chief State School Officers (CCSSO).

Widdowson, H. G. 1994. The ownership of English. TESOL Quarterly 28(2): 377-88. https://doi.org/10.2307/3587438.

Zawiah Yahya. 2015. Method in the madness: Teaching of English literature in Japanese universities. 3L: Southeast Asian Journal of English Language Studies 21(3): 25-40.

.2003. Nations and narration: The problematics of writing Malaysia in English. In Reclaiming places and spaces: Issues in new literatures, eds. Ruzy Suliza Hashim and Subramaniam G. Bangi: Universiti Kebangsaan Malaysia Press.

Zawiah Yahya, Noraini Md Yusof, Noraini Ibrahim and Zarina Othman. 2015a. Your Language My Culture: A reading programme Form 1 (Student copy). Bangi \& Kuala Terengganu: Penerbit Institut Kajian Malaysia \& Antarabangsa (IKMAS, Universiti Kebangsaan Malaysia) dan Yayasan DiRaja Sultan Mizan. .2015b. Your Language My Culture: A reading programme Form 1 (Teacher Copy). Selangor \& Kuala Terengganu: Penerbit Institut Kajian Malaysia \& Antarabangsa (IKMAS, Universiti Kebangsaan Malaysia) dan Yayasan DiRaja Sultan Mizan. 
Zawiah Yahya et al.

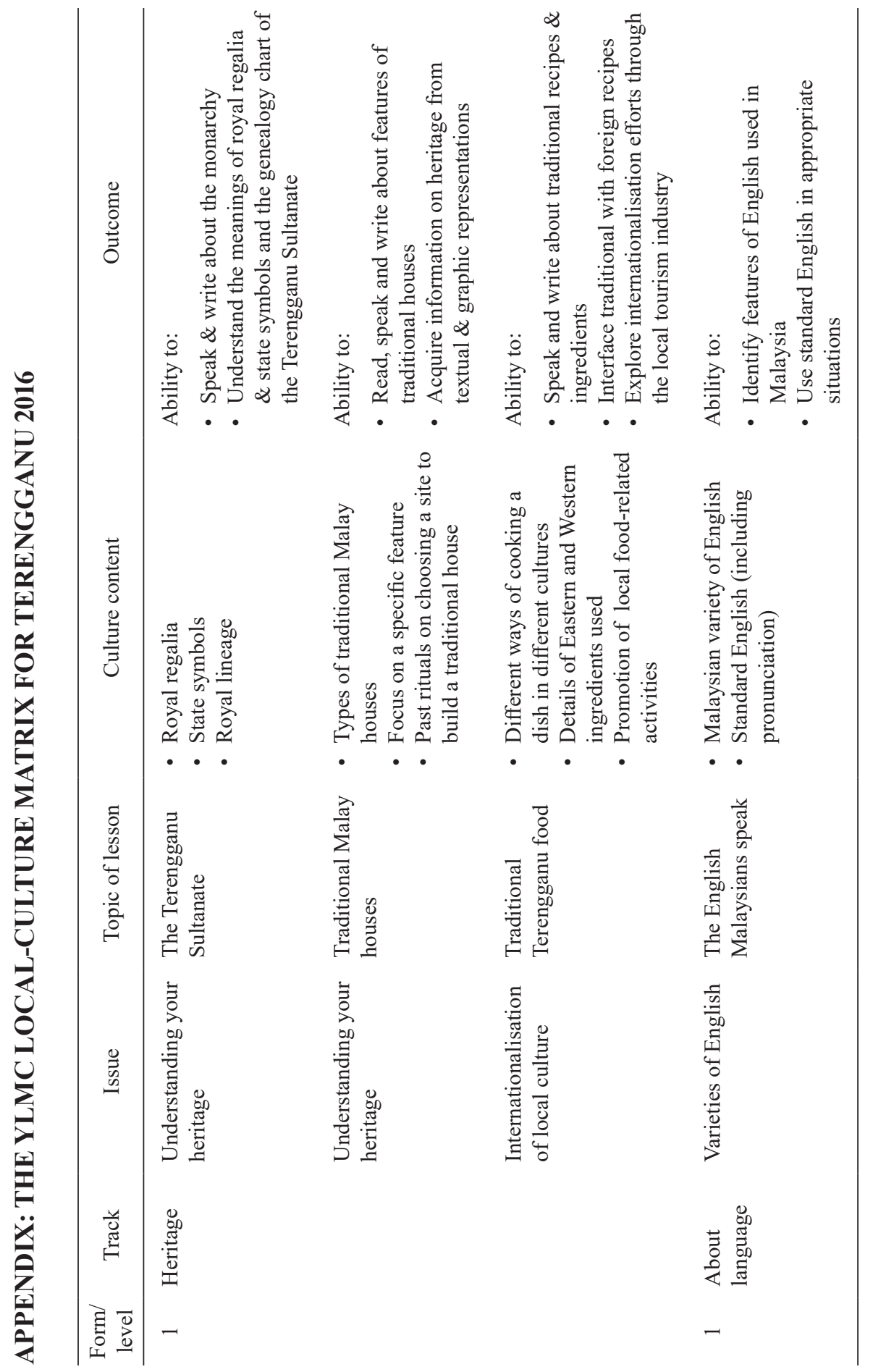


Your Language My Culture: A Local-Culture ELT Matrix

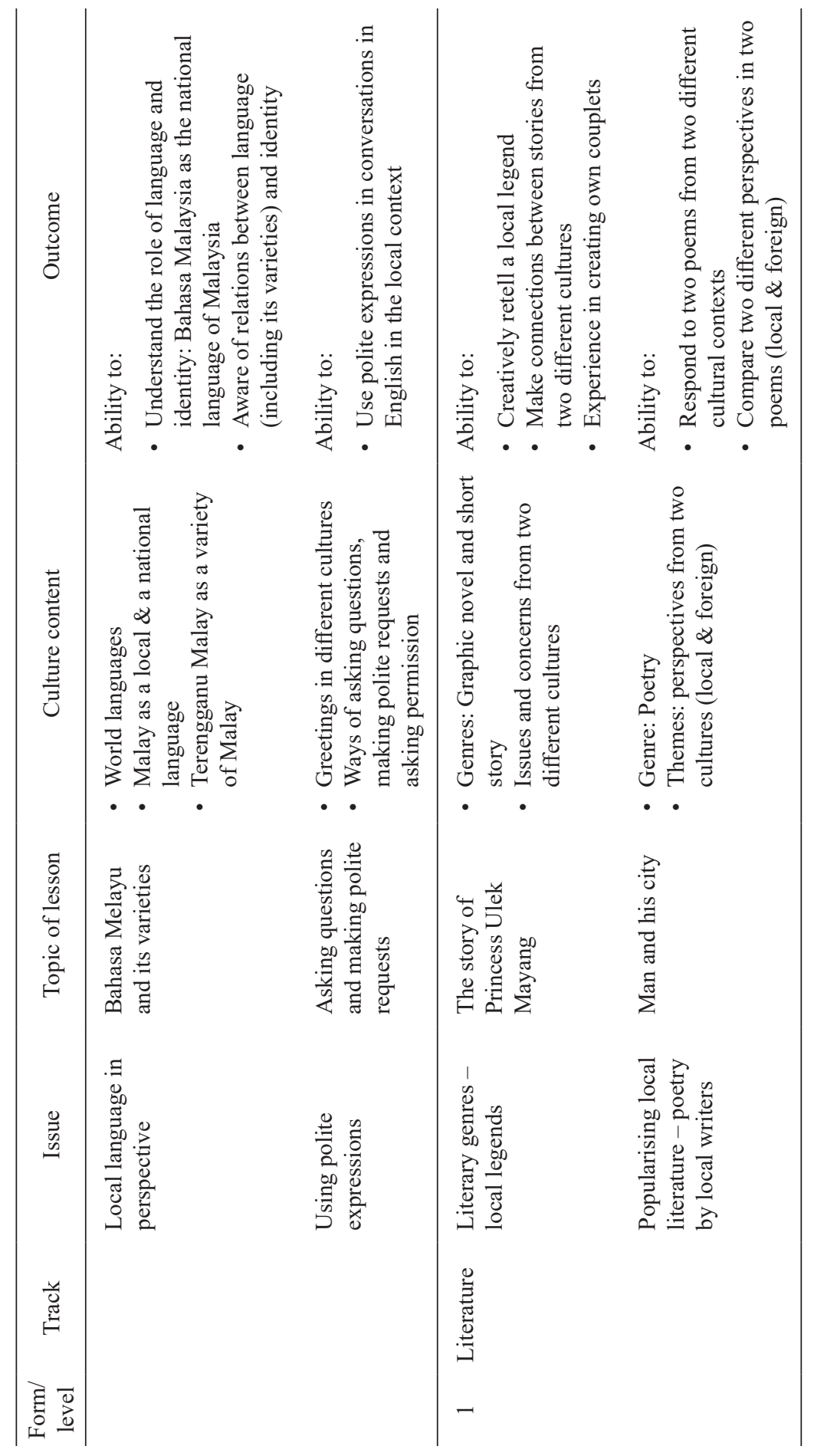


Zawiah Yahya et al.

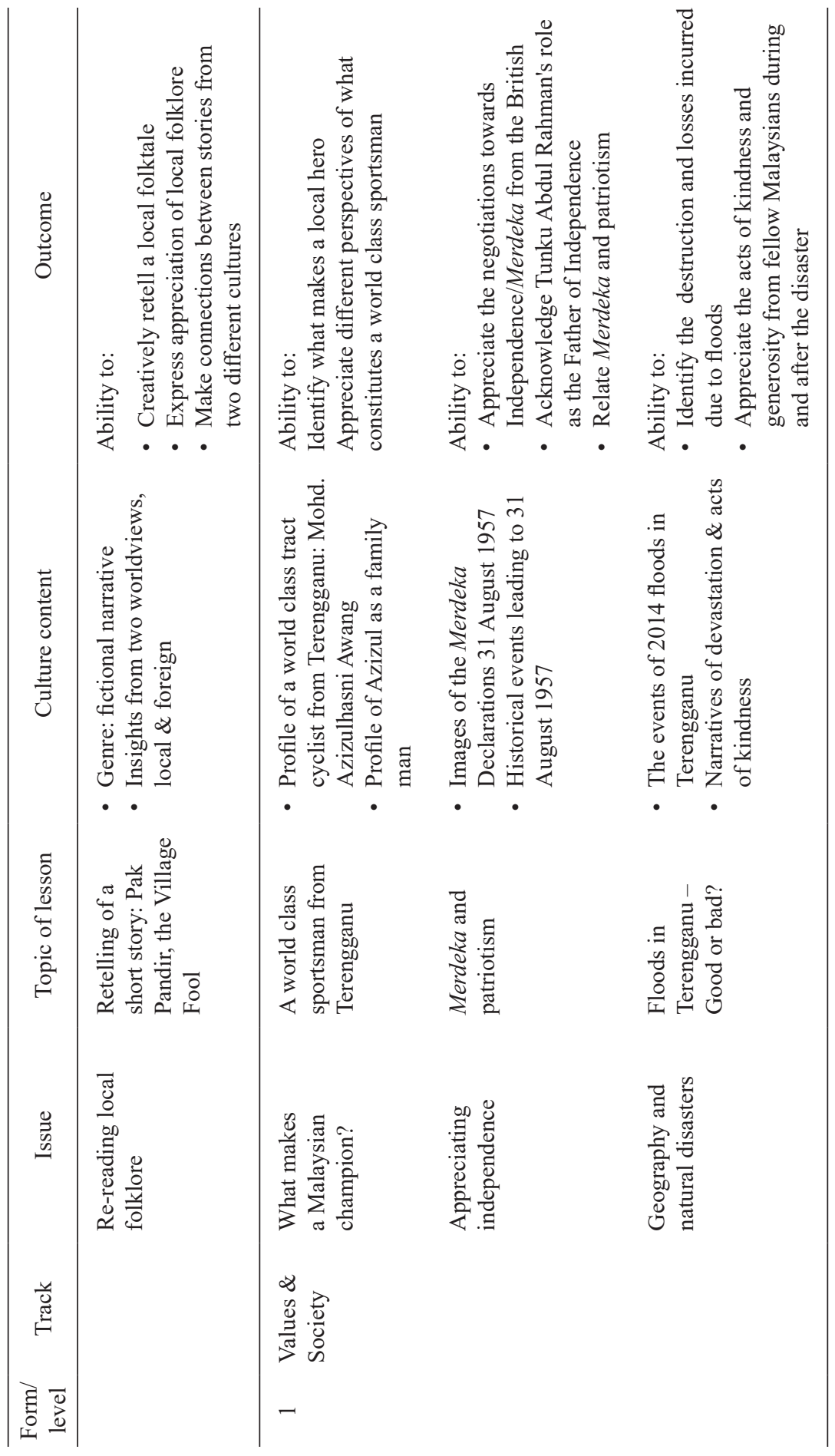




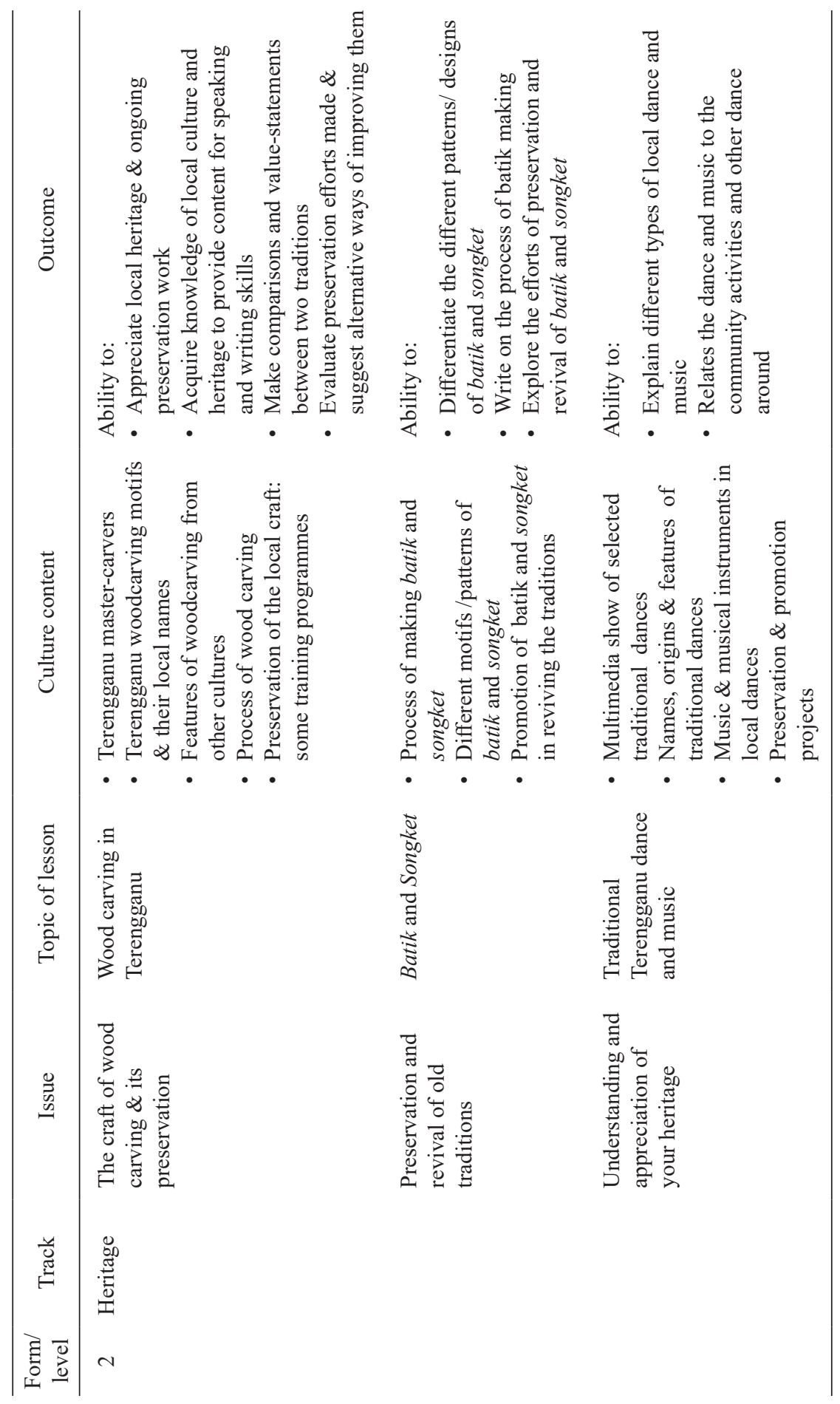


Zawiah Yahya et al.

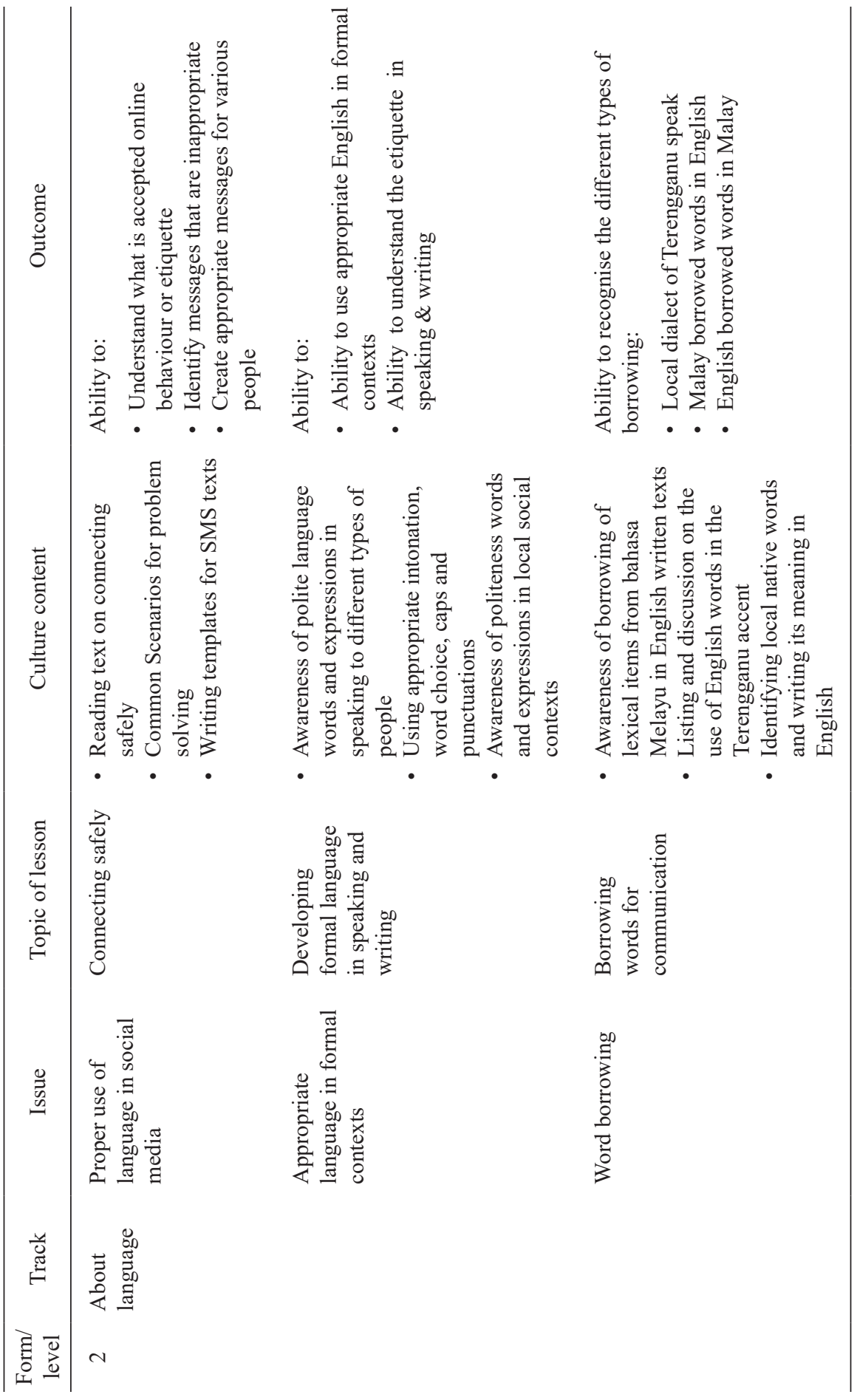




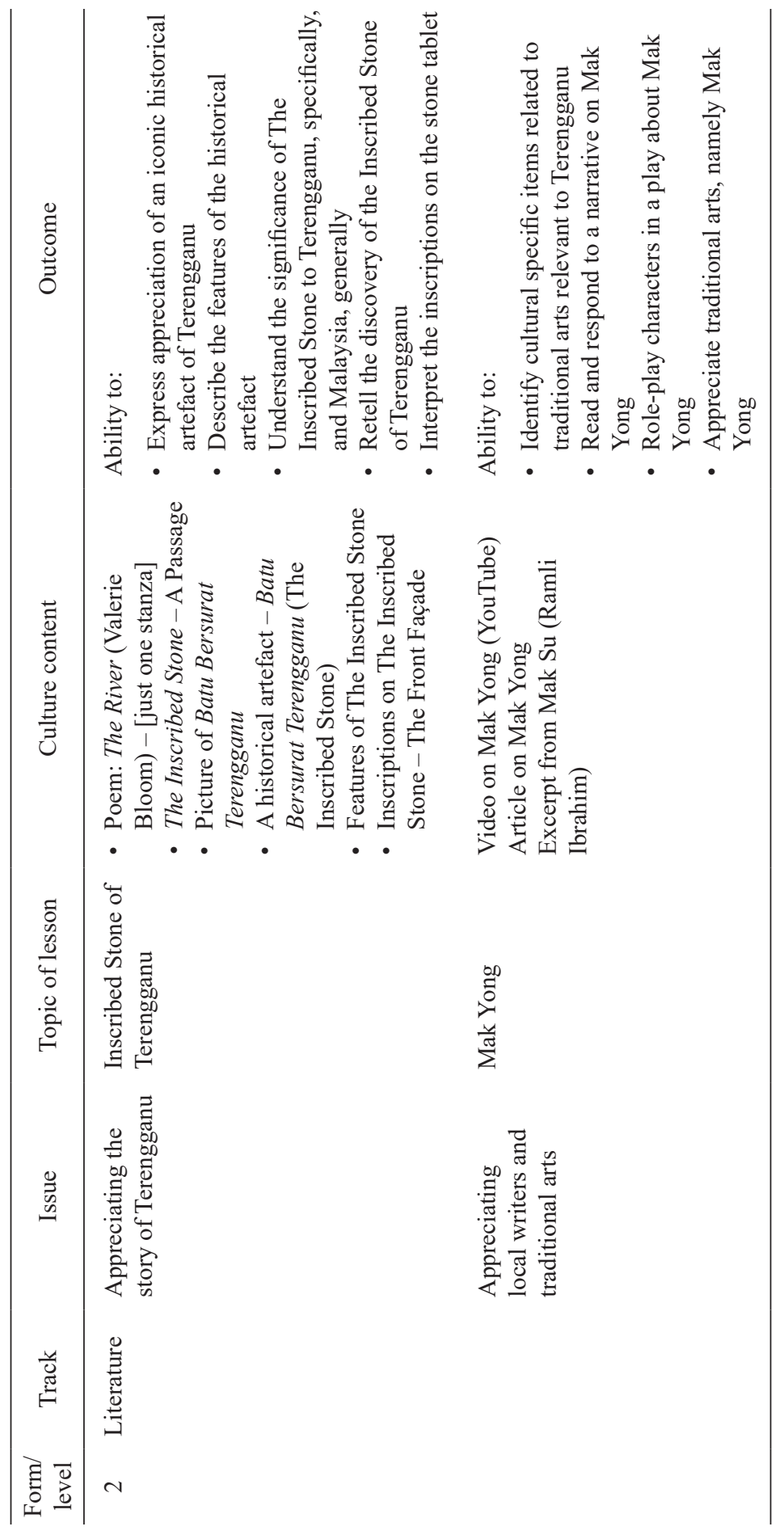




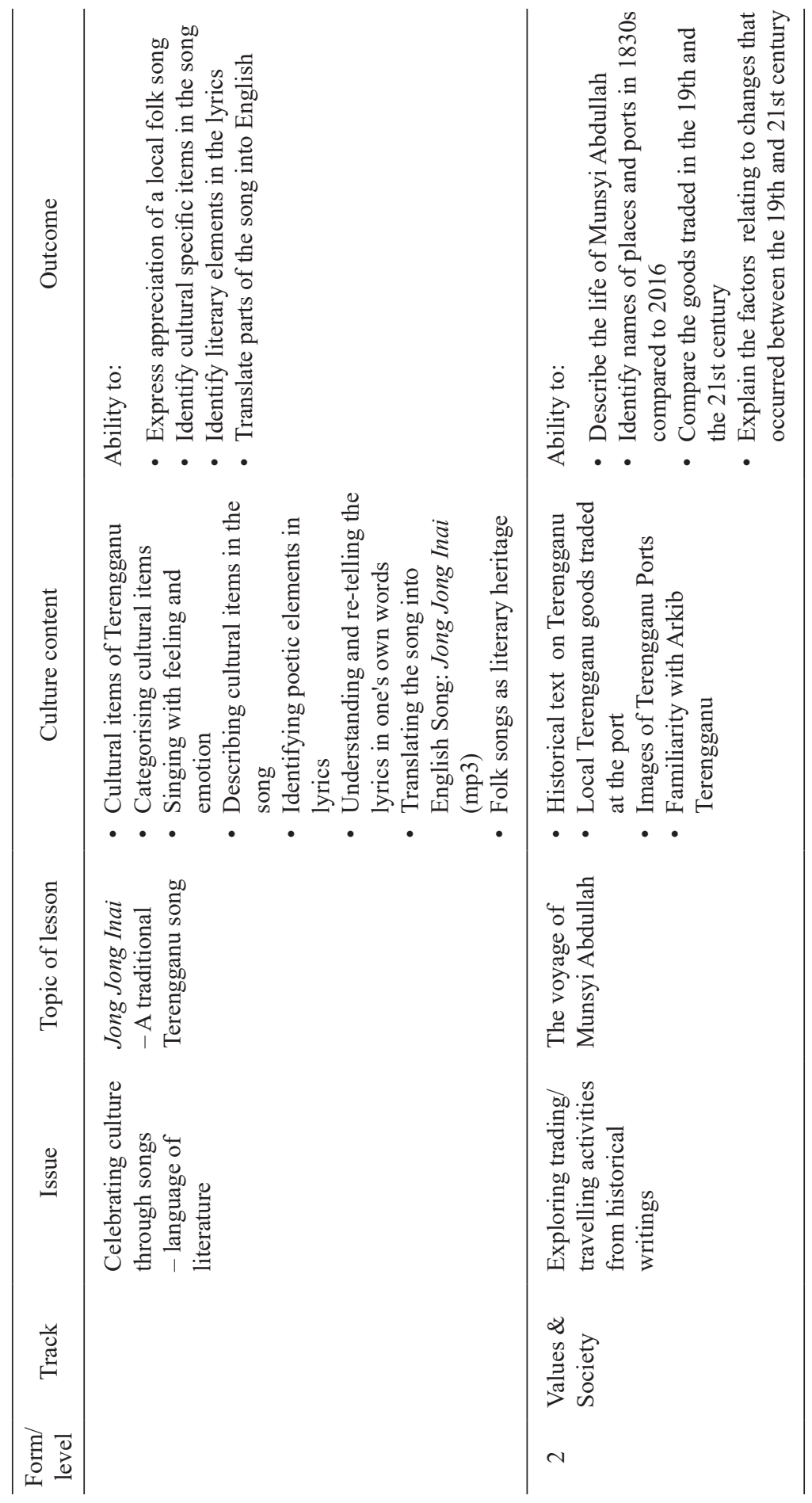




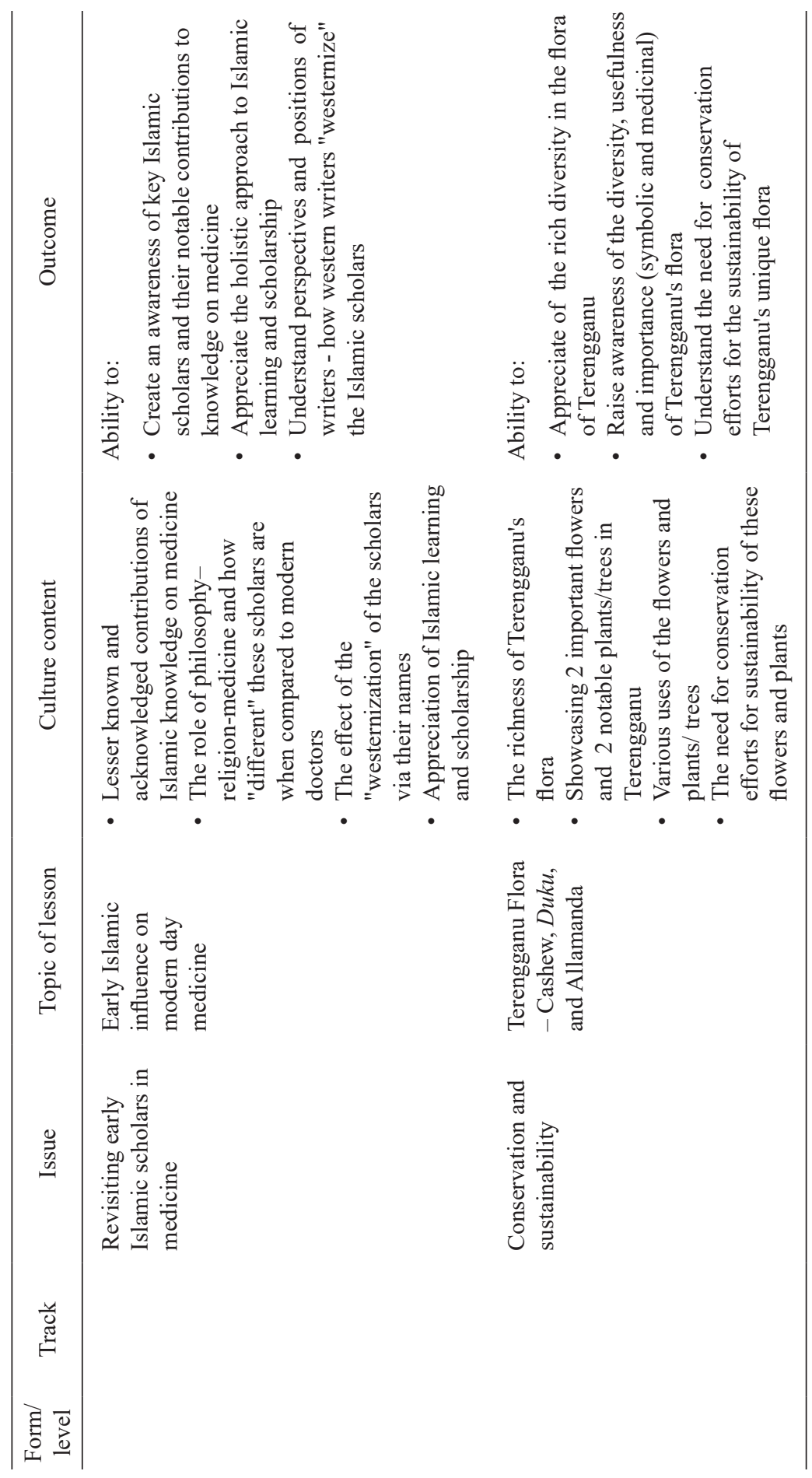


Zawiah Yahya et al.

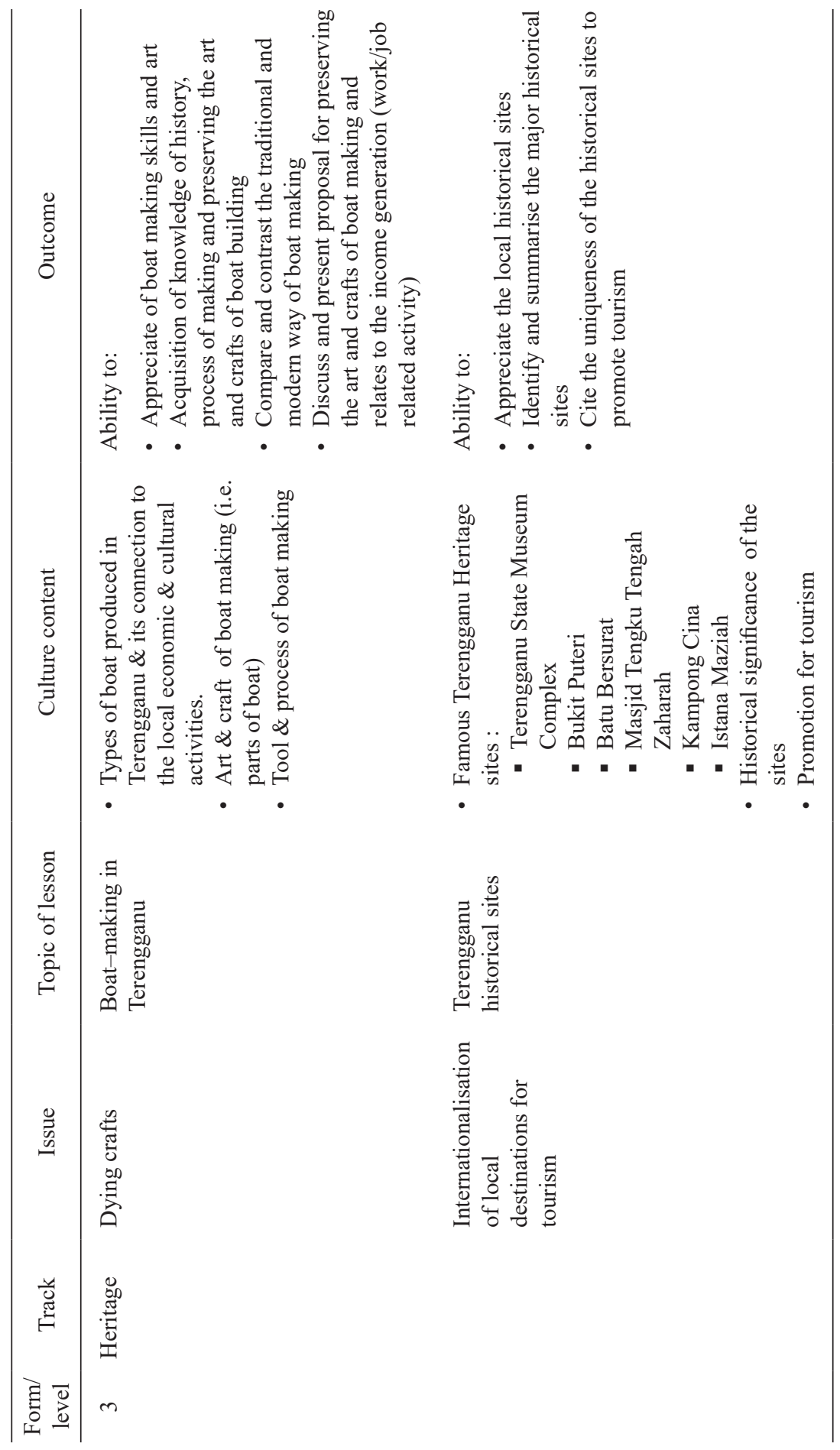




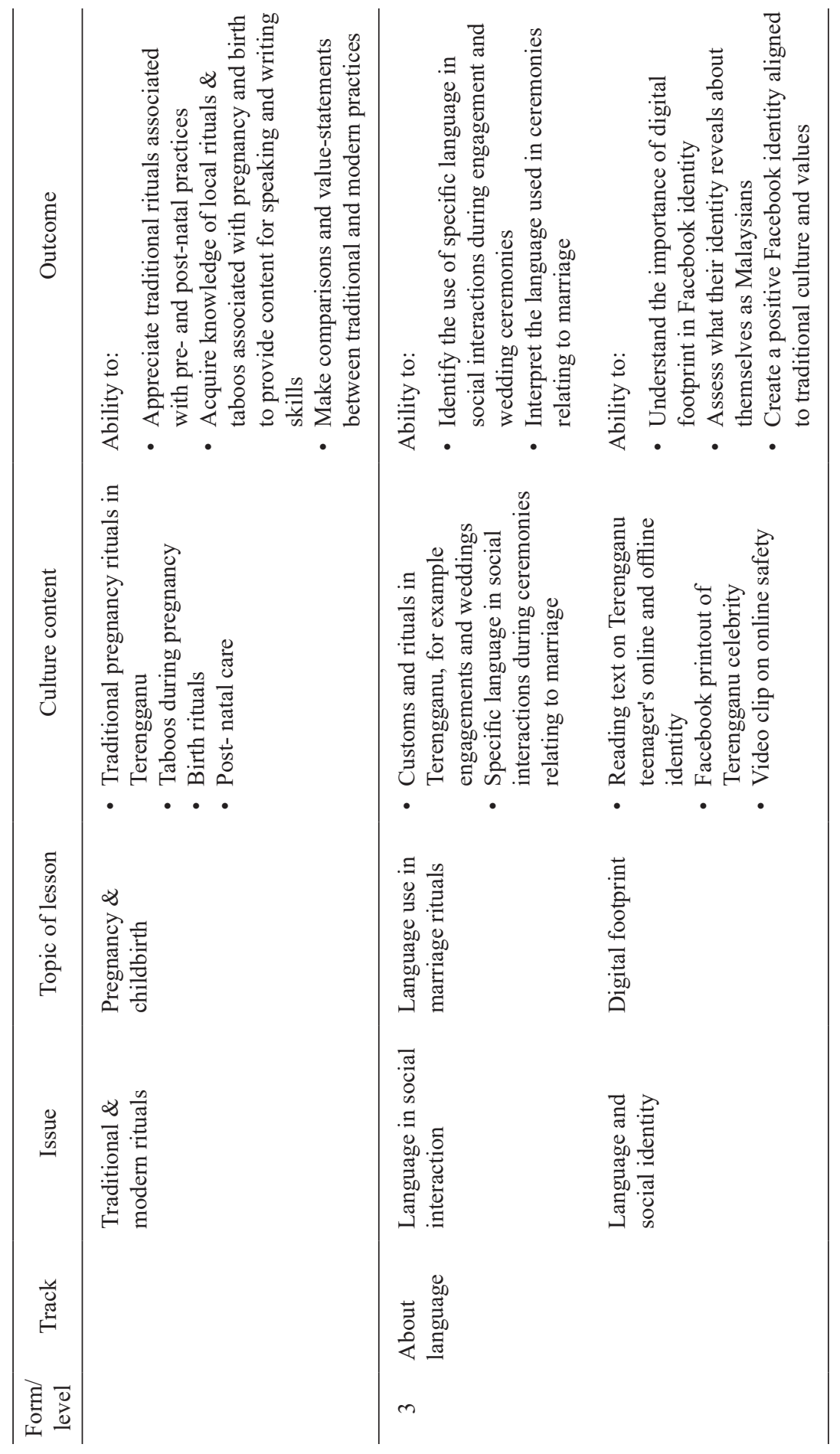


Zawiah Yahya et al.

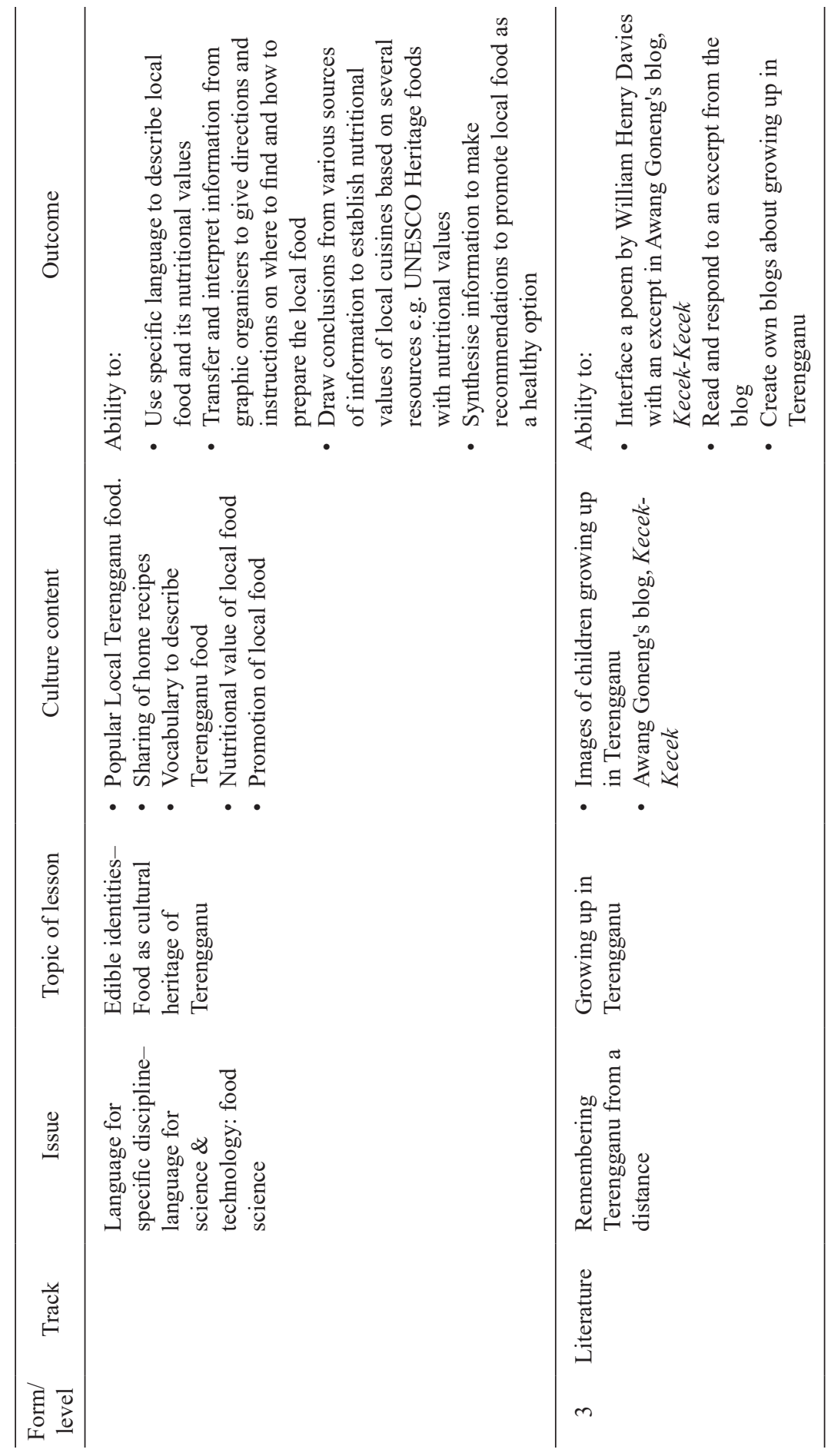


Your Language My Culture: A Local-Culture ELT Matrix

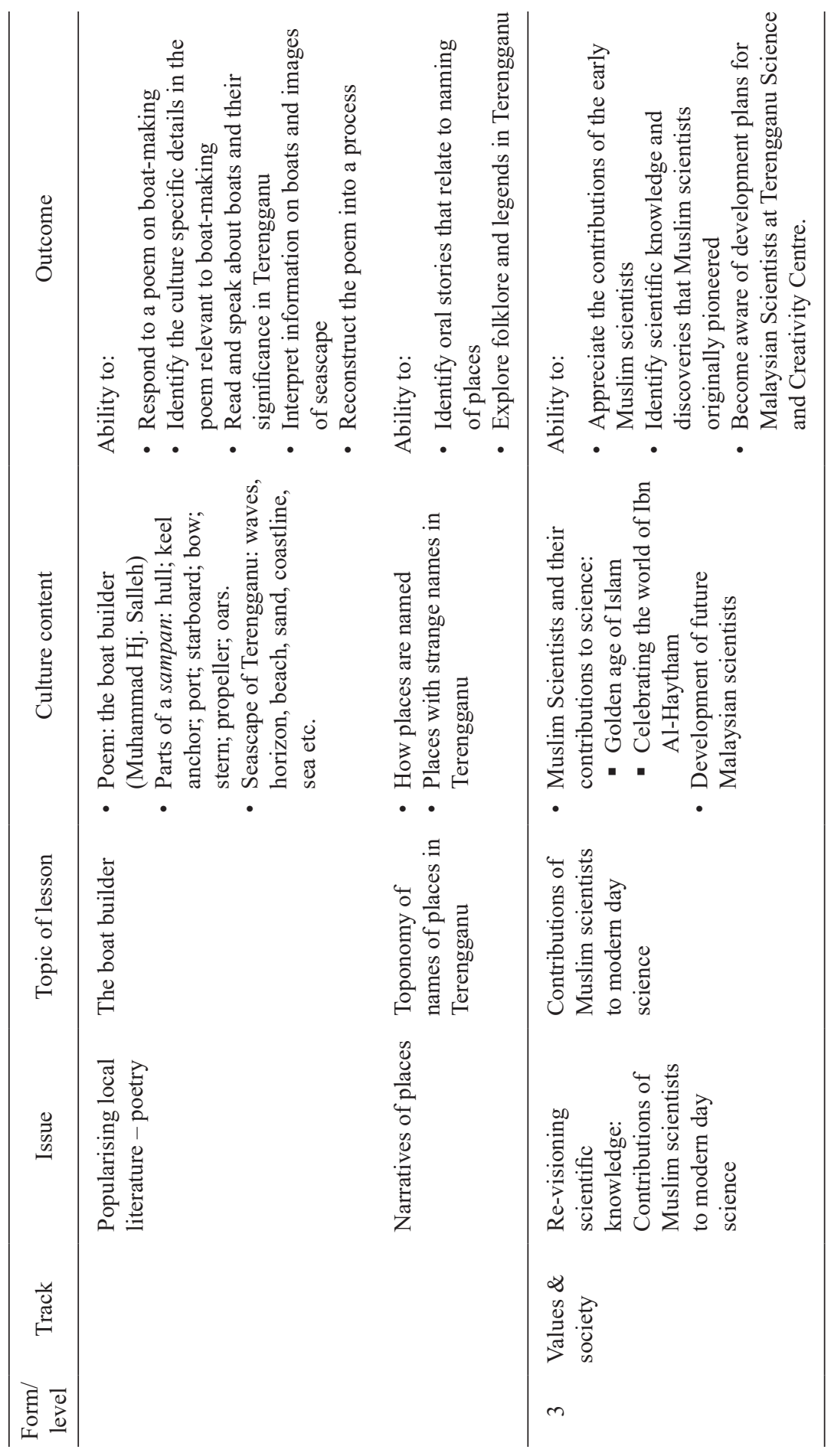


Zawiah Yahya et al.

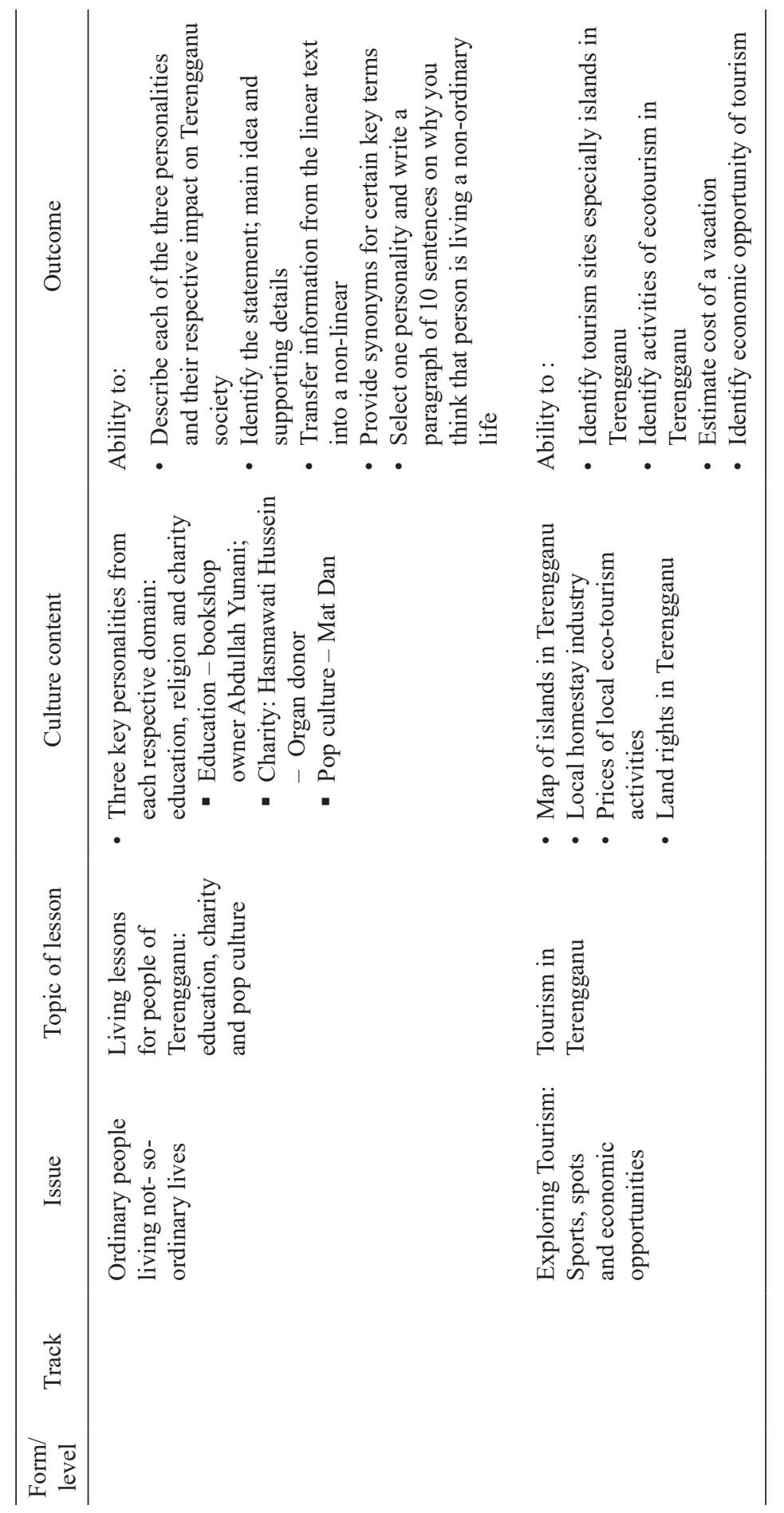

